\title{
The book of Revelation - an early Christian 'Search for Meaning' in critical conversation with its Jewish heritage and Hellenistic-Roman society
}

\begin{tabular}{|c|c|}
\hline $\begin{array}{l}\text { Author: } \\
\text { Michael Labal }\end{array}$ & \\
\hline $\begin{array}{l}\text { Affiliations: } \\
{ }^{1} \text { Unit for Refor } \\
\text { and the Devel } \\
\text { of the South } \\
\text { North-West U } \\
\text { Potchefstroon } \\
\text { South Africa }\end{array}$ & $\begin{array}{l}\text { med Theology } \\
\text { opment } \\
\text { frican Society, } \\
\text { hiversity, } \\
\text { Campus, }\end{array}$ \\
\hline $\begin{array}{l}{ }^{2} \text { Martin-Luthe } \\
\text { Halle-Wittenb }\end{array}$ & $\begin{array}{l}\text {-University } \\
\text { erg, Germany }\end{array}$ \\
\hline $\begin{array}{l}\text { Corresponden } \\
\text { Michael Labah }\end{array}$ & $\begin{array}{l}\text { ce to: } \\
n\end{array}$ \\
\hline $\begin{array}{l}\text { Email: } \\
\text { am.labahn@t- }\end{array}$ & online.de \\
\hline $\begin{array}{l}\text { Postal addres } \\
\text { Kantor-Wurm } \\
\text { D - } 38446 \text { Wo } \\
\text { Germany }\end{array}$ & $\begin{array}{l}\text { Strasse 1, } \\
\text { fsburg, }\end{array}$ \\
\hline $\begin{array}{l}\text { Dates: } \\
\text { Received: } 18 \\
\text { Accepted: } 23 \\
\text { Published: } 18\end{array}$ & $\begin{array}{l}\text { pr. } 2014 \\
\text { ept. } 2014 \\
\text { Dec. } 2014\end{array}$ \\
\hline $\begin{array}{l}\text { How to cite th } \\
\text { Labahn, M., } 2 \\
\text { 'The book of } \\
\text { an early Christ } \\
\text { for Meaning" } \\
\text { conversation } \\
\text { heritage and } \\
\text { Roman societ } \\
48(1) \text {, Art. \#18 } \\
\text { http://dx.doi.c } \\
\text { ids.v48i1.1833 }\end{array}$ & $\begin{array}{l}\text { is article: } \\
14, \\
\text { evelation - } \\
\text { ian "Search } \\
\text { n critical } \\
\text { vith its Jewish } \\
\text { ellenistic } \\
\text {, In die Skriflig } \\
33,9 \text { pages. } \\
\text { rg/10.4102/ }\end{array}$ \\
\hline $\begin{array}{l}\text { Copyright: } \\
\text { (C) 2014. The A } \\
\text { Licensee: AOS } \\
\text { OpenJournals. } \\
\text { is licensed unc } \\
\text { Creative Comn } \\
\text { Attribution Lic }\end{array}$ & $\begin{array}{l}\text { uthors. } \\
\text { S } \\
\text { This work } \\
\text { ler the } \\
\text { nons } \\
\text { ense. }\end{array}$ \\
\hline Read online: & \\
\hline 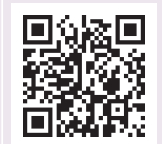 & $\begin{array}{l}\text { Scan this QR } \\
\text { code with your } \\
\text { smart phone or } \\
\text { mobile device } \\
\text { to read online. }\end{array}$ \\
\hline
\end{tabular}

The book of Revelation's attitude towards its political, religious and social environment is a radical one: Revelation 18:4 asks the readers to leave the city of Babylon, less so they do not become victims of God's punishment, but so that they do not share the sins of this city. Such a narrative program is a counter-cultural access that leads its adherents into isolation at the edge of ancient society. On the other hand, the narrative incorporates pictures and ideas from different ancient milieus. By this, the narrative shows a profound understanding of political, religious and cultural streams. It shows a creative reception and a reworking of motifs or themes into a new literary entity, in terms of producing something new instead of ignorance or simple negation of reality. The rhetoric of good and evil and the subversive power of the autobiographic narrative make the usage of ancient culture a dangerous rhetorical weapon compared to the more dialogical approach to ancient culture used in other Christian groups. John's narrative is witness of an approach that integrates and selects insights from different religious streams, from 1st century Judaism and 1st century Christianity into a selective and limited model of Christian attitude towards society and culture. The narrative is not simply conservative but integrative in developing new revelation on old ground, whose counter-cultural access is based on the transformation of different cultural means. Therefore, the article describes the apocalyptic and antagonistic strategy of the book of Revelation as a complex technique of exchange and transformation of religious or cultural ideas and motifs.

Die boek Openbaring - 'n vroeëre Christensoeke na betekenis in kritiese gesprek met sy Joodse herkoms en Grieks-Romeinse gemeenskap. Die boek Openbaring se benadering tot sy politieke, religieuse en sosiale omgewing is ingrypend: Openbaring 18:4 versoek die lesers om die stad Babel te verlaat - nie so seer om God se straf vry te spring nie, maar veral om nie in die stad se sondes te deel nie. Sodanige narratiewe program is ' $n$ kontra-kulturele benadering wat die volgelinge daarvan tot die rand van die antieke gemeenskap marginaliseer. Aan die ander kant inkorporeer hierdie narratief ook beelde en idees uit verskillende antieke milieus. Hierdeur demonstreer die narratief ook 'n diepgaande begrip van politieke, religieuse en kulturele strominge. Dit toon 'n kreatiewe resepsie en 'n verwerking van motiewe of temas tot 'n nuwe literêre entiteit in terme van die voortbring van iets nuuts in plaas van die ignorering of blote ontkenning van die realiteit. Die retoriek van goed en kwaad en die subversiewe mag van die outobiografiese narratief maak die gebruik van die antieke kultuur 'n gevaarlike retoriese wapen in vergelyking met die meer dialogiese benadering tot die antieke kultuur soos dié van ander Christengroepe. Johannes se narratief getuig van 'n benadering wat verskillende religieuse denkrigtings van die eerste eeuse Judaïsme en Christendom integreer en selekteer tot 'n selektiewe en beperkte model van die Christelike gesindheid teenoor samelewing en kultuur. Hierdie narratief is nie alleen konserwatief nie, maar ook geïntegreerd met die ontwikkeling van nuwe openbaring op ou gronde - openbaring met kontra-kulturele toegang gebaseer op die transformasie van verskillende kulturele middele. Hierdie artikel beskryf dus die apokaliptiese en antagonistiese strategie van die boek Openbaring as 'n komplekse tegniek van wisselwerking en transformasie van religieuse of kulturele idees en motiewe.

\section{Introduction}

\section{Understanding the world through apocalyptic rhetorical transformation}

It might sound curious to start with the book of Revelation when dealing with the relationship between the Bible and society. We might overlook that the message and the imagery of the book of Revelation is present in contemporary thought, including all aspects of contemporary secular art (cf. for example Mazenik 2011:190). For instance, there would be no classical motion picture 
like Francis Ford Copula's 'Apocalypse Now'1 without the inspiration of the book of Revelation, which is often called 'The Apocalypse' and which is understood as a narrative of the catastrophic events that lead to the end of human history. In their narratives, modern imitators of Revelation reflect 'repressed unease about the present, aimlessness, hopelessness, lack of vision [...] but also indifference, horror on concernment, and pleasure in the imagination of doom', which might at least be part of their model too. ${ }^{2}$ Nevertheless, Revelation is neither told to follow the principle of individuality and the postulate of self-realisation' nor to meet crises 'with mellowed distance'. ${ }^{3}$ Revelation constructs a meaningful narrative world that counters the social and political world.

This article tries to introduce this hermeneutical project of opposition to a social and political situation in Roman society and under Roman power. No other early Christian text is so closely related to the society outside its textual world and offers such a critical interpretation of the world outside as Revelation does with its inner-textual world of thought. This is what makes it sensible to include a discussion of this text in a conference on the role and influence of biblical values on social change. Moreover, the apocalyptic worldview inspired by Revelation and its critical interpretation of ancient society has been influential throughout the centuries and has had an impact on political thinking and political theories maybe even until today. The separation of the political world into East and West, into good and bad (especially fostered by the Reagan-Bush era that saw the United States of America as opposed to an 'Evil Empire') $)^{4}$ was inspired by the apocalyptic structure and thought of Revelation. This holds true even if we want to discuss if such an influence was a direct one or if it was rather caused by the trace of collective memory ('Gedächtnisspur') (Karrer 2005:419). The term axis of evil, coined by former United States president George W. Bush, in a speech on 29 January 2002, was so influential that it has received its own entry in Wikipedia. ${ }^{5}$ Again, it was inspired by the message of Revelation. Already in the aftermath of the 9/11 attacks, Bush invited his allies to 'answer these attacks and rid the world of evil'.6

Revelation itself develops such an apocalyptic rhetoric that divides its narrative world into good and evil. The reader finds, on the one hand, God and his agents, and, on the other hand, the devil and figures that do his work (cf. Labahn 2011a; 2013b; see also Schreiber 2013). The narrative 'axis of

\section{Cf. the excellent analysis by Bachmann (2005)}

2.Cf. Busse (2000:222): 'Verdrängtes Unbehagen an der Gegenwart, Ziellosigkeit, Auswegslosigkeit, Visionslosigkeit [...] aber auch Gleichgültigkeit, Grusel am Betroffensein und Lust an der Imagination des Untergangs'. A number of studies from social sciences, cultural and literary studies deal with apocalyptic though in recent narrative art, including films, novels, comics and popular music (cf. for example Busse 2000; Krah 2004).

3.According to Busse (2000:223), the modern answer to apocalyptic narrative follows 'dem Individualitätsprinzip und dem Selbstverwirklichungspostulat, er begegnet Krisen mit abgeklärter Distanz'.

4.Cf. the short remarks in the Wikipedia (n.d.b) article 'Reich des Bösen'.

5.Wikipedia (n.d.a) article titled 'Axis of evil'.

6.Quoted by Räisänen (2009:155), referring to Maier (2005:294-307). evil' aims at 'leading the world astray' from God's and the Lamb's intentions. ${ }^{7}$ Such a narrative world does not develop ex nihilo - it comes into being from a critical conversation with its Jewish heritage, the cultural and religious legacy of Hellenistic-Roman milieu, and finally its Christian contemporaries. The formation of this religious text originated in transformation of ideas from its different traditions.

In a country that has managed a peaceful way to overcome a policy of opposites, this article does not want to deal with the impact of the rhetoric of the book of Revelation on political thinking in general. ${ }^{8}$ It rather aims to describe the narrative apocalyptic and antagonistic strategy of the book of Revelation as a complex technique of exchange and transformation of religious or cultural ideas and motifs. This article only refers to a small sample of case studies. The term transformation, used in this article, refers to a process through which existing religious concepts, views or patterns are integrated into a new literary setting that, taken together, forms a new religious framework. This article analyses Revelation as a narrative writing with an aim to form meaning by construction of the reality of its readers put into a meaningful, clearly structured narrative world. The book of Revelation develops:

1. a story that is Christian in nature, although opposing other Christian groups and concepts (cf. Rv 2-3);

2. a story that is deeply rooted in Jewish thoughts, although it is opposed to the social or political behaviour of certain Jewish groups that are said to be in relation to the devil

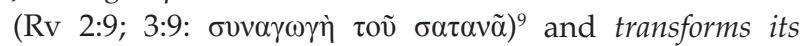
heritage in taking its own interpretation of the Scriptures of Israel as an interpretation of the eschatological proclamation of God's will;

3. a story opposing Hellenistic-Roman religious ideas, yet also picking up its imagery and finally demonising the political establishment and its religious system of meaning from the edge of society. ${ }^{10}$

In the midst of this complexity we might not find Revelation as an example of a clash of different religious systems. The narrative of Revelation develops the world of its readers into a radical religious system, which, for sure, is not an example of a modern sophisticated and peaceful dialogue between different religious systems. It might rather be taken as an example of how religious groups or individuals evade frustration and/or feelings of suppression. The narrative forms meaning by transforming older traditions and

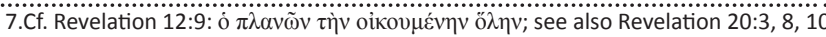
and 2:20 (Isebel), 13:14 (the second beast), 18:23 (the whore Babylon) and 19:20 (false prophet). Cf. Labahn (2011a:33)

8.Perhaps, at least, the development of liberation theological thoughts due to the interpretation of Revelation by Boesak (1987) should be considered here.

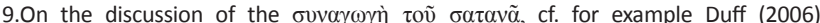
Frankfurter (2001); Friesen (2006:134-141); Lambrecht (2001) and Stowasser (2013).

10.The fact that the book of Revelation presented an approach to the Roman Empire from the edge of ancient society is underscored by the recent commentary of Wengst (2010). However, it is misleading to call the book of Revelation a text that comes 'from the perspective of the lowest and most tangential classes, that is from the perspective of the victims' (Wengst 1994:196). It is part of the rhetorical from the perspective of the victims' (Wengst 1994:196). It is part of the rhetorical strategy of the narrative to take over the position of being a victim, but
hints that the author or his addressees belonged to the lowest classes. 
challenging religious ideas into a new radical system from an outsider's position.

If such a system merely helps to form the identity of a group of outsiders because it is a piece of fantastic ${ }^{11}$ subversive narrative (Labahn 2014), ${ }^{12}$ Revelation might simply be an interesting religious document to be studied. It might also be an inspiration to overcome absolute systems of ideology or ways of thinking. However, the moment such a system is used by a leading group or leads to violence against others or against people within the own group boundaries as sometimes happens in apocalyptic sectarian groups, it becomes a dangerous instrument of suppression.

\section{On the historical and literary setting of Revelation}

Revelation tells the story of a man called John, who is introduced as its author and who receives Revelation from God himself, which is of and from Jesus Christ (Rv 1:1). John was at the place called Patmos, to which he was confined because of his belief in the Word of God and the testimony

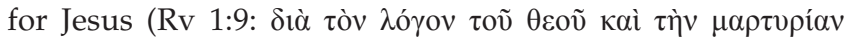
'I room (Rv 4-5). From this beginning a story develops, which tells how history is brought to a God-given end through catastrophes and a war that destroys the opponents of God and all their followers. Finally, at the end of the narrative and after final judgement (Rv 20:11-15), a new geographic entity is presented, called 'New Jerusalem' (Rv 21:1-6),

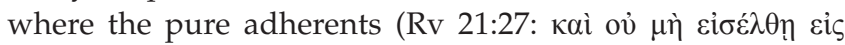

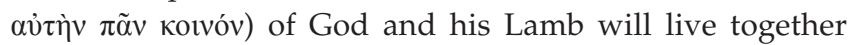
with God and the Lamb in paradisiacal peace (cf. especially Rv 22:1-5).

The story, which is written in what would be perceived as a critical and often offensive dialogue amongst Christian communities and in opposition to the Roman authority, could be called a 'subversive narrative'.13 It depicts the Roman Empire, which seems to stand firmly for the view of the addressees outside the narrative, as a social and political entity that has, according to the plot of the story, already fallen and will finally fall at the end of human history (cf. for example Rv 12:9, 14:8, 18-20; especially 18:2). All readers or hearers who follow the pragmatic of the story and who share the view of the narrative will look at their environment, especially at the Roman Empire, in a completely different manner after reading the narrative of Revelation. According to the rhetoric of Revelation, the

\footnotetext{
11. On the question of the relation of (ancient) fantastic literature and the story of Revelation, cf. Frenschkowski (2005:41-45).

12.On Revelation as 'subversive narrative', cf. Labahn (2014).

13.On 'subversive narrative' cf. Rustemeyer 2000. On Revelation: Wengst (2010:22), who includes Revelation into 'subversive Untergrundliteratur', Venetz (1999) and Porsch (2000). For a narrative interpretation of Revelation, cf. for example Resseguie (2009) and his introduction to narrative studies on Revelation, and Resseguie (1998). Of basic importance is also Boring (1992). Wherever the discussion of the literary genre of Revelation may lead, it cannot be denied that the book is an 'I-narrative', which establishes its own narrative world and social space (cf. Labahn 2011b. It aims to 'construct meaning' by narrating the history space (cf. Labahn $2011 \mathrm{~b}$. It aims to 'construct meaning' by narrating the history
of the addressees - on the importance of narrativity to construct meaning, cf. for of the addressees - on the importance of narrativity to const
example Rüsen 2006:30) from a 'heavenly' point of view.
}

earthen power is related to the besieged satanic reign and therefore that power is besieged by a more powerful power: the kingdom of God. The story of Revelation is subversive in constructing a new reality within the text that has an effect on understanding the world beyond the text.

Revelation was probably written at the end of emperor Domitian's reign in the western part of the Roman province Asia Minor. Such a dating remains the most probable one, although some scholars have recently proposed a later date. Such a theory, to a great deal, corresponds to the textual data of very intense pressure from the political power. It presupposes an intensity of the Roman emperor's cult that some scholars take for granted as historical reality in the time of the later emperor Hadrian (Witulski 2007). ${ }^{14}$ Yet, it might be doubtful that the intensity of the veneration of the Roman emperor changed that much between the reign of emperor Domitian to that of the later emperors Trajan or Hadrian in the first part of the 2 nd century.

However, the main doubt is raised from another observation. Even if the argument of any development of the emperor's cult may be true, it cannot be overlooked that the storyline of the book of Revelation develops its own construction of a narrative world that is in accordance with its apocalyptic idea. We should not doubt that the story is a construction related to the world outside the story with its cults and religious and social reality. However, as part of its apocalyptic worldview, the narrative radicalises the social situation of the Christian communities - a radicalisation of reality ('Radikalisierung der Wirklichkeit'), as it is called by Harald Ulland (1997) - presenting a situation of political and religious pressure, ${ }^{15}$ and in doing so forcing its contemporary readers to decide between God and a compromising life in Roman society. ${ }^{16}$ According to the storyline, the situation of the Christian communities in Western Asia Minor becomes a situation that endangers their lives. Keeping belief in Christ meant, according to the narrative world of Revelation, to risk physical death, yet gaining eternal life, which is already depicted in the story as a contemporary reality (cf. Labahn 2012; see also Nicklas 2009; cf. Rv 6:9-11; 7:9-17; 14:1-7; 15:2-4).

As such, it might be a view from the edge of society, yet it radicalises the edge unto further marginalisation ${ }^{17}$ by showing that getting outside the Roman social world is a place where true power sets free. With this, finally, the edge is changed to become the centre of Christian life.

14.Cf. also the discussion on the late dating between Witulski (2012) and Witetschek (2012). Witetschek refuses a late date and Mucha (2014) argues, with good proof, for the classical date of Revelation at the end of Domitian's reign.

15.A number of recent studies have clearly revised the picture of persecutions of Christians during the reign of Domitian; cf. for example De Villiers (2002).

16.See also Collins (1984:111): 'John adapted oral and literary anti-Roman tradition into a particularly fierce and dualistic literary image of the insurmountable opposition between the servants of God and the servants of Rome. He highlighted and emphasized the suffering of Christians at the hands of Rome and painted a picture of the empire which put this trait of persecutor at the very center.'

17.It somehow reminds of Gerd Theissen's theory of self-stigmatisation as developed with a view to early Christian proclamation (Theissen 2003:162ff.). 


\section{Revelation as transformation of its religious heritage and milieu - Some examples}

As a fantastic subversive narrative, the book of Revelation is a witness of the formation of a new Christian-bound religious system that opposes social reality whilst transforming its own religious heritage and even using religious ideas from outside. Revelation takes a radical approach by separating its own system from its sources (the scriptures of Israel), from its natural allies (other Christian groups) and from its opponents.

\section{Jewish background and its transformation}

Reading the story of Revelation, it is first of all an apocalyptic book on God and his agents who fight an apocalyptic war against the evil at the end of time and finally destroys the evil power. The story itself is developed from motifs, thoughts, pictures and words from the Jewish scriptures, which are taken up in a very creative and free way - a method that, in the context of Jewish exegesis, is not completely unique. ${ }^{18}$ However, the claim of Revelation to form a new scripture that is essential to remain unchanged ( $R v$ 22:18-19), and which will lead into the new community with God and the Lamb in 'New Jerusalem', might be unique (cf. Labahn 2013a). ${ }^{19}$

Jewish monotheism seems to be the basic religious and ethical model for the storyline of Revelation. On the basis of such a theocentric worldview (Schnelle 2008:714; Söding 2001), other religious systems are estimated as evil and as representing idolatry and harlotry $(\operatorname{Rv} 2: 14,20 ; 9: 20$; see also Rv 14:8; 17:2, $4 ; 18: 3,9 ; 19: 2 ; 21: 8 ; 22: 15)$. Revelation wants people to avoid any compromise with such impure entities and to follow the right side in the final eschatological war. People are fostered

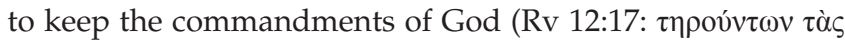

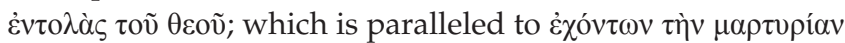

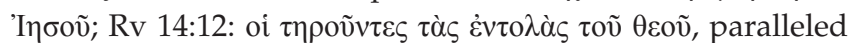

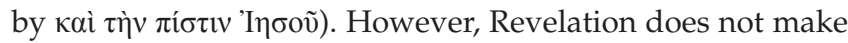
use of the classical Jewish boundary markers, such as Sabbath observance and circumcision. The term Israel is mentioned three times: neutrally or slightly negatively in Revelation 2:14, and positively in Revelation 7:4 and 21:12 - and always referring to the people of Israel. ${ }^{20}$ We can find a reference to the heroes of Jewish social memory in Revelation 4:4 and 10, if the group of 24 elders included a reference to the $12 \mathrm{Old}$ Testament prophets and the 12 apostles. We also find the list of the 12 tribes in Revelation 7:4-8, which might refer to Israel or to members of the Christian community - perhaps Jewish Christians.

These Jewish elements of religious thinking, especially the monotheistic, theocentric idea, form the main part of the overall religious concept behind the apocalyptic narrative of

18.cf. for example the study of Ego (2006), on contemporary Jewish interpretation of the book of Ezekiel compared to its reception in Revelation. See also Dochhorn (2011), on Revelation as 'schriftgelehrte Prophetie' within the context Jewish exegetic methods.

19.On Revelation 22:18-19, see for example Hieke and Nicklas (2003:68-82), and Tilly (2005).

20.On Israel in Revelation, see Hirschberg (1999).
Revelation. Such elements build a background for a Christological line of thought that develops more than accidentally. Christology has become part of the monotheistic argument; the concept of purity is related to Christian communities; the Jewish heroes have Christian companions; there is hope for a new community without temple (Rv 22:3-4), hence creating a new and immediate community between God and the Lamb and its now Christian adherents. Different elements of Jewish identity are taken up positively and are transferred into the narrative world of Revelation. These representations of Jewish identity become part of the Christian transformation of their previous Jewish background.

Within this transformation process, it is frightening that Jewish assemblies are called the 'Synagogue(s) of Satan'

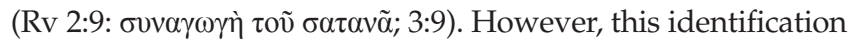
does not indicate anti-Semitism in general, because it does not contain a general ethnic religious claim. It is rather related to a certain political behaviour ascribed to particular Jewish circles. These groups are called 'Synagogue(s) of Satan', because, according to the rhetoric of the narrative, these people act in cooperation with Satan. This means that they act in a way that endangers Christian groups or individuals so that they leave their fellowship with Christ. The problem behind the polemic identification might best be recognised as an act of denunciation against the Roman authorities in that there are certain Christians who did not honour the emperor. Such collaboration might havehappened as somekind of self-defence or as an act of differentiation from other Christian groups to show loyalty towards the Roman power. The most adequate historical background for such behaviour can be taken from the correspondence of Pliny the Younger and Emperor Trajan (Letters 10.96, 97). Although the correspondence comes from a later period, the situation described in the letters of Pliny might refer to a legal practice that was already in use much longer.

The storyline of Revelation construes a real conflict that produces a dynamic self-defence and consequently identity limits. Formation and limitation are due to certain actions and not to an intellectual or religiously motivated limitation although Revelation calls these acts of denunciation 'blasphemy'

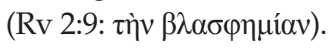

In general, the Jewish background - Karlheinz Müller calls it a Jewish-Christian competence ${ }^{21}$ - is transformed into a Christian religious concept that includes a high Christological approach with a very strict and apocalyptically motivated opposition to any pagan kind of religion.

\section{Transformation: Christianised monotheism and radicalism}

During the history of the interpretation of Revelation, there has been a discussion as to whether the Jewish part of Revelation might be separated from the Christian elements by means of literary criticism, for example Eberhard Vischer (1886). Other exegetes merely regard Revelation as a slightly Christianised document. Both kinds of interpretation seem to be misleading. Even if older traditions, or maybe even 21.Müller (2011): 'judenchristliche(.) Kompetenz'. 
literary layers, could be identified - which seems somewhat doubtful - the actual plot is grounded in a Christological concept. Next to God, Christ appears already as a co-source of blessing in the letter greeting of Revelation 1:5-6. Christ is the first figure John sees in heaven when he is taken by the spirit on the Lord's Day (Rv 1:10-20). If Christ, as the central figure as well as the different Christological terms and motifs, were deleted from the text, the plot would not work anymore.

The different figures representing Christ are main characters of the story and form an integral part of the narrative of Revelation. Of central importance is the figure of the 'lamb'. The figure of the 'lamb' in the narrative of Revelation is a transformation of Jewish ideas and is developed into a special 'symbol' of early Christian Christological claims. It is not completely sure from which stream of tradition the 'lamb' is taken. Some scholars refer to the Pesach lamb, ${ }^{22}$ other to Isaiah 53 , other to the 'tamid offering' and so on. The Lamb is both a figure of weakness and a figure of power. As the slaughtered ( $\operatorname{Rv} 5: 6: \dot{\omega} \varsigma \dot{\varepsilon} \sigma \varphi \alpha \gamma \mu \varepsilon \dot{v} v v, 9)$, the Lamb refers back to the cross,

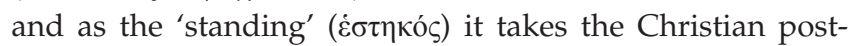
Easter perspective of resurrection. The wound remains a part of the characterisation of the Lamb throughout the narrative and also reminds of the fate of the Christian followers, according to the perspective of Revelation (Schreiber 2008). The Christians risk being killed if they follow the Lamb and God's commandments, but they also benefit from the Lamb in a twofold way: from its bloodshed at the cross as well as from its resurrection (Labahn 2012). As the slaughtered, the Lamb is close to the readers' experience of being endangered (not necessarily persecuted) by Roman power.

However, the figure does not only have a soteriological function, but also serves the progression of the narrative plot and is a part of the apocalyptic rhetoric. For this reason the Lamb is portrayed with seven horns and eyes that look all around the world ( Rv 5:7), so that this Lamb is not only powerful, but also informed about everything that is happening outside heaven in the human world. ${ }^{23}$ As such the Lamb is the only figure able to open the seal of the book of the seven seals, which inaugurates the apocalyptic drama $(\mathrm{Rv}$ 5:1-14). Thus, Christology is transformed into an apocalyptic plot from which the whole story is set into motion.

All Christological portraits are presented very close to God. Already the exalted Son of Man (Christ figure) of Revelation $1: 12-20$ is portrayed alongside symbols, motifs and texts that are traditionally reserved to the portrait of God or to ancient deities. The monotheism of the story transforms the Jewish concept into an early Christian concept that includes the newly presented Christ figure.

We might add other aspects of transformation of ancient apocalyptic and monotheistic Jewish patterns into the early

22.Cf. now, for example, Giesen (2012), who does not assume any atoning function for the Pesach lamb, but refers to an apotropaic effect, which he finds in the backdrop of the Lamb figure in Revelation.

23.On the background and interpretation of Revelation 5:7, cf. Labahn (2010: 406-408).
Christian concept of Revelation. Such an apocalyptic model merely works as a basic element for the plot of the whole book. Combined with a theocentric approach and a rigoristic view of purity, there is no place for any kind of compromise or proximity to other religious concepts. Purity, keeping the commandments of God and believing in the Lamb (Christ figure), can only be maintained if Christians turn away from any of the surrounding religious activities, including, for instance, public meals or festivals of the ruler cult or social and economic activities in ancient associations.

The book prescribes a very restrictive system of identity formation that draws boundaries not only with regard to social interchange with pagan religious groups and behaviour, but also with regard to groups within the Christian movement that apply for a more open approach and exchange with ancient society. Christian interpretation of ancient deities, which may follow the Pauline argument of 1 Corinthians 8:4 that 'no idol in the world really exists'

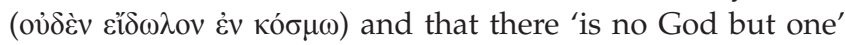

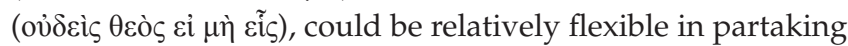
in social life in Greco-Roman cities, not fearing to pollute themselves with regard to ancient deities. According to the argument of Revelation, such an interpretation is regarded as an act of impurity and disobedience. Those open-minded Christian groups are described as minorities that come from outside into the communities (cf. Rv 2:6, 14, 15, 20, 24). Such a description may belong to a polemic or apocalyptic construction of the story itself. Compared to Revelation, more liberal Christian models of living in an ancient society are criticised by motifs from Scriptures, for example, such Christian groups are associated with Bileam (Nm 22-24; see also Nm 25:1-3; 31:16) and Isebel (1 Ki 16:29-33; 18:13, 19). Furthermore, they are criticised for claiming to have

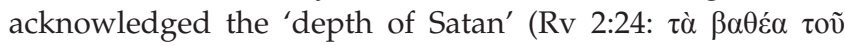
$\sigma \alpha \tau \alpha v \tilde{\alpha})$ and are associated with the besieged anti-figure Satan (cf. Labahn 2011a:38-39). Although, it might be asked if this is part of the self-definition of those liberal Christian groups, somewhat related to Paul's statement about the power of the

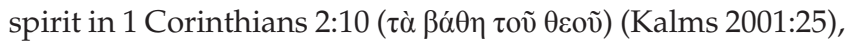
it is more convincing, against the background of the story, to read it as a transformation of any self-understanding into the interpretation of Revelation. According to the rhetoric of Revelation, any liberal Christian approach takes the risk of leading Christian followers astray from God and his Lamb and is therefore related to the work of Satan.

In the setting of the letters to the churches ( $R v 2-3)$, the accusation that those liberal Christian groups make themselves guilty of 'prostitution' and the 'eating of food offered to idols' includes all aspects of compromising with ancient religious movements and does not seem to single out the emperor's cult alone. Pagan cults seem to have had some attractiveness for Christian converts. However, it might be plausible that engaging in social interaction - either as a way of commerce ${ }^{24}$

24.cf., for example, Siitonen (2011), who opts that with the commercial imagery Revelation does not only touch on the issue of idolatry, which is related to the Revelation does not only touch on the issue of idolatry, which is related to the
criticism of Roman Empire and its imperial cult, but also deals with certain Christian merchants and their relation to Roman economy. 
or in taking over public responsibilities - means compromising with other groups and their religious ideas, which, according to the model of Revelation, presents an act of impurity.

It is not really possible to analyse the background or social and religious identity of these more liberal Christian movements or groups - whether a single group or various groups. Much information is hidden beneath the polemical schematisation of the actual context in the text. The liberal group(s) might go back to a post-Pauline or liberal interpretation of Paul, but the position does not seem to be too far away from other developments and transformations within the early Christian movement in relation to the social religious milieu outside the Christian movement. Opposite to such ideas, the religious Jewish-Christian system of Revelation transforms Christianity into a social and religious entity that locates itself at the edge or even outside ancient society in an elitist style.

\section{Ancient religion}

The narrative of Revelation incorporates various texts, pictures and ideas built upon ancient culture as well as its philosophical or religious ideas. ${ }^{25}$ Through such a strategy, Revelation shows a profound knowledge and understanding of various ancient political, religious and cultural systems.

To give just a few examples:

- The risen Christ in Revelation 1:16 is portrayed with a face

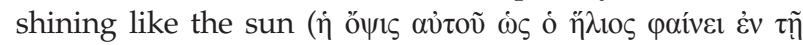

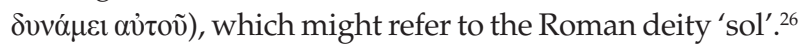

- The story of the pregnant woman in Revelation 12 takes up elements from the myths of Isis or Seth-Typhon (respectively Leto or Python), which seems to be already influenced by polemic against the Roman emperor's propaganda (Omerzu 2006; see Van Henten 2006). David Balch (2006) has shown that some of these elements are prominent in ancient art, so that there are potentially different ways of influence that may be taken into account.

- In Revelation 9:11 the angel of the bottomless pit as the leader of the locust together with his army of locusts ( Rv 9:3, 7) refer to Apollon Parnopios (Karrer 2012:228-230). Here, the narrative setting uses material from pagan religiosity to develop a new plague, showing that Apollon does not give rescue, but rather causes death and danger.

Dochhorn protests searching for parallels in so-called pagan religiosity as background of the story of Revelation, especially

25.Cf., for example, the presentation of data in Karrer (2013). Many texts and motifs from ancient religious contexts are presented as part of the encyclopedic presentation in the commentary of Aune (1996-1998).

26. Revelation 1:16: 'and his face was like the sun shining with full force'. Karrer (2012:227): there is 'ein bewusstes Spiel mit dem Namen des Sonnengottes ... Christus trägt - besagt es - den Glanz des himmlischen Gottes, des Helios-Sol, wie der Apoll der Völker und entmachtet die katachthonischen Götter' [There is an intentional play with the name of the sun God [...] Christ - so it says - carries the shining of the heavenly God, of Helios-Sol, like Apoll of the nations and disempowered the katachtonic gods]. See also Böcher (1983:55): 'Wenn der disempowered the katachtonic gods]. See also Bocher (1983:55): Wenn der Herrscher Roms sich mit dem Sonnengott Mithras bzw. Sol Invictus identifizieren und mit dem Siebengestirn in der Rechten darstellen ließ, dann bekennt der Apokalyptiker durch die analoge Darstellung des erhöhten Christus (Apk 1,16.20, 2,1), daß sein Weltherrscher und Helios Jesus heißt' [When the emperor of Rome identifies himself with the sun gods Mithras or Sol invictus and when he gets portrayed along the Pleiades in his right hand the apocalyptic writer confesses that his ruler of the world and his Helios is called Jesus due to such an analogous presentation of the risen Lord] with regard to Revelation 12 (Dochhorn 2011:20-21), ${ }^{27}$ but this point of view is too one-sided. Looking at the whole story, it becomes rather plausible that there is an intended openness to both biblical-Jewish traditions and HellenisticRoman motifs. At least with regard to readers, we cannot exclude the Hellenistic-Roman background, yet it seems more probable that the book of Revelation is deliberately bipolar - it is related both to biblical-Jewish traditions and the Hellenistic-Roman background. Some passages even use material from the portrait of pagan deities to portray God or Christ or their activities. Others, marked by their narrative setting, are used to describe plagues and destruction to diminish these deities by means of the narrative flow. The narrative neither shows ignorance nor simple negation. It rather develops a creative transformation and reworking of ancient ideas whilst incorporating them into a new literary entity - even melting together imagery from the biblicalJewish traditions and the Hellenistic-Roman milieu at the same time. Using the attractiveness of ancient cultural or religious ideas may strengthen the rhetorical power of the narrative of Revelation. The heroes of the book are portrayed as being superior to the heroes of ancient culture and/or religion - even using elements taken from these fields in their own characterisation. On the other hand, the heroes, stories or motifs become part of a caricature, especially with regard to the emperor's cult. The apocalyptic rhetoric of good and evil and the subversive power of its autobiographic narrative make the use of ancient culture a dangerous rhetorical weapon.

\section{Emperor's cult}

In many approaches to Revelation, the emperor's cult and its opposition are seen as a major, if not the main, hermeneutical key for understanding the entire book (cf. for example Wengst 1994:189-190; 2010). As we have seen from the observations mentioned above, such an approach is a little too simplistic:

1. On the one hand, there is not one overall emperor's cult that is the same in all the different locations to which Revelation is addressed (cf. Ameling 2011:24-36). There is a basic structure of claims, but even that is too farreaching to reconstruct a 'theology of the emperor's cult', as done by Stephan Witetschek (2008:131). Anyhow, such a unifying tendency of the cult of the Roman emperor is part of the rhetoric strategy and the narrative construction of reality by Revelation that radicalises the political situation outside the story. Such a construction turns the empire, the emperor and his cult into one entity that is empowered by Satan and belongs to the 'axis of evil' (cf. especially Rv 12:18-13:2), and which will be finally defeated in the apocalyptic war and judgement (cf. Rv 17-20).

2. One main part of Revelation's dispute with Roman rule and its cultic representation is the literary form of its polemic renarration. Roman representatives become characters in the story that are associated with Satan and are therefore regarded as a part of the apocalyptic 
enactment. It starts with the fall of Satan from heaven ( $R v$ 12:9) and continues his furious but already besieged activities on earth ( $R v$ 12:17) where Roman rule is introduced as his allied figures until his final defeat ( $R v$ 12:18-13:18). Thereby, Roman rule and power are transformed from a powerful reality in ancient Asia Minor outside the story into a powerless character that has already been defeated, since it is placed on the wrong side in the apocalyptic drama.

3. On the other hand, elements from the emperor's cultic enactment or from the emperor's propaganda are used to describe God or his Christ, or are at least paralleled to enactments or descriptions of Christ and God. In Revelation 1:14 the eyes of Christ as the heavenly son of man are described to be 'like a flame of fire' ( $\dot{\omega} \varsigma \lambda \lambda \dot{o} \xi$ $\pi v \rho o ́ s)$. The description is based on the intertwined verses Daniel 7:9 and 10:6. However, the final portrait of the risen Christ has parallels to a similar description of the emperors Augustus (Suetonius Aug 79.2) and Domitian (Statius Silvae I 1.99-104). The portrait shows the power of Christ as superior to other rulers as it is described in their own propaganda.

4. In the heavenly worship, the 24 elders hail God as 'the

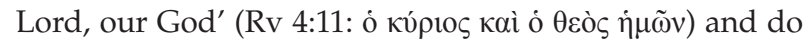
the proskynesis in front of God's throne - a habit that reminds of the behaviour of besieged rulers in front of the emperor. The acclamation of God recalls Septuagint language (Ps ${ }^{\mathrm{LXX}}$ 34[35]:23; 35[36]:15; 87[88]:2), but also reminds of a title that was used with regard to emperor Domitian (Suetonius Dom. 13.2; Martial 10.72). ${ }^{28}$ The almighty God (Rv 4:8) sits on his heavenly throne, which, according to the plot of Revelation, is also a countersymbol to earthen political power, since the real power will finally overcome in the eschatological war.

5. These examples show that different elements were taken from ancient religious systems, but at least they become part of a new story. As far as they are not used to describe the narrated opponents in the story, they are reserved for Revelation's formation of meaning (inside the text), so that its use by another figure outside the text may be viewed as a kind of misuse.

6. Other elements from the emperor's propaganda that could beidentified in the book of Revelation were taken up through a negative narrative setting. If, for instance, the rider of the first white horse in Revelation 6:2 is not a positive figure and does not represent Christ, ${ }^{29}$ then it describes a figure that acts parallel to what happens in a Roman triumphal procession. Such a reference has a highly critical potential. What is meant to guarantee the (Roman) audience the peace and benefit that the Roman ruler provides to his people,

28.Cf. Labahn (2002:157-159), and Timpe (2009:216): 'Die Anrede dominus et deus gehört [...] vermutlich zu den politisch relevanten Formen sakraler Uberhöhung der kaiserlichen Stellung Domitians, sie war anscheinend ein Ausdruck seines auffälligen Sendungs- und Auserwähltenbewusstseins und wurde deshalb von auffalligen Sendungs- und Auserwahltenbewusstseins und wurde deshalb von gewiegten Adulatoren zielstrebig eingesetzt ' [The address dominus et deus probably belongs [...] to the most politically relevant forms of sacred elevation of the imperial position of Domitian, it apparently was an expression of his remarkable consciousness of being sent and determined and was therefore purposefully used
by adulators].

29.As it is presented, for example, by Michael Bachmann in many well-argued articles (recently Bachmann 2012) is, according to the rhetoric of Revelation, only the start of a new war that brings hunger, death and devastation, as elaborated by the next three riders ( $R v$ 6:3-8). Without mentioning the idea of the pax Romana, the narrative setting portrays a concept similar to the pax Romana as an empty propaganda myth. This interpretation does, of course, not only belong to the political claims and realities of the Roman Empire itself, but rather recalls a concept of an apocalyptic worldview that leads to more and more disasters, yet eschatological hardships at the end of time.

7. Most interesting is that the story of Revelation also uses a very special form of comic mimesis to describe the soteriological claims of the emperor's propaganda. In Revelation 13:3, the animal from the sea is described with reference to the Lamb. It has a wound that is healed

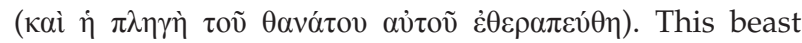
imitates God and the Lamb as a challenge to the real ruler of the world (God) and the life he brings. The use of the participle $\dot{\varepsilon} \sigma \varphi \alpha \gamma \mu \varepsilon \dot{v} \sigma \varsigma$ is provocative: elsewhere it refers to the slaughtered Lamb ( $\operatorname{Rv} 5: 6)$, whose blood brings real life ( $\operatorname{Rv} 7: 14 ; 12: 11)$. The repetition of the image suggests an attempt to imitate the Lamb, but the analogy is incomplete: only one head of the beast appears to be 'slaughtered,' and even this head has only a potentially deadly wound - one that could be (and has been) healed. All in all, the depiction of the wound of the beast is more a caricature of the slaughtered and newly living Lamb than an imitation. The animal represents the emperor and, as such, he claims to give peace and prosperity to the people, including economic welfare. In short, Roman propaganda claims that the ruler will bring peace and salvation to the inhabitants of the Roman Empire. Many ancient inscriptions praise the salvific acts of the emperor or his local representatives. According to the storyline of Revelation, their saving attitude is a false claim, so that it rather needs to be reckoned as a caricature of the true salvation given by the true God and his Lamb/Christ.

By the presentation of Roman rule, the emperor and the emperor's cult are transformed according to the apocalyptic story of Revelation. The story seems to understand that the ruler's cult contains challenging claims for peace and salvation as well as for religious veneration opposed to its own religious concept. Those claims are taken so seriously that the political reality is presented in a distorting mirror (Esch-Wermeling 2011:160) by being caricatured and placed in a negative narrative setting, demonised or regarded as claims that were only legitimately used in the context of the heroes of Revelation's story.

The controversy with the emperor's cult is not directed at a conversation with the Roman contender. There are no apologetic aims in the arguments of the story. The hassle refers to Christian group(s). On the one hand, Roman rule together with its propaganda and cultic enactments held a certain fascination, so that Christians might follow the cult. ${ }^{30}$ On the other hand, there was also pressure effected 30.Cf. Revelation 13:3-4, 8 and the interpretation by Pezzoli-Olgiati (2002:231-232). 
by economic needs, social communication and even denunciation that forced Christians to compromise or even depart - this might have been caused by suppression of local Roman administration. Furthermore, there was some kind of development in the Christian thinking itself - starting with Paul - that lead to a more open approach to the challenges of ancient society, including its religious systems. These developments are also criticised by the rhetoric of Revelation so that its radical view, which leads people unto the edge of ancient society or even further away, also represents an inner-Christian controversy with regard to the challenges of the Roman emperor's cult. The dispute with other Christian religious ideas therefore has an identity building function by developing religious and social group limits.

\section{Conclusion}

Revelation is only one voice within the choir of early Christian literature, yet a very special and radical one - even if it is debatable whether the approach should be called 'radical'. Revelation 18:4 asks the readers to leave the city of Babylon, less so they do not become victims of God's punishment, but so that they do not share the sins of this city. In Revelation, Babylon is a cipher for the city of Rome, but by Revelation 18:4 the city already stands for more: the entire social, religious and political reality ${ }^{31}$ that belongs to the power of Rome as city and empire. Non-cooperation in the structures of society is the goal of the ethics of the seer, aiming at the preservation of an own religious identity. Such a narrative program is clearly not a strategy for cultural diversity, but rather a counter-cultural access that leads its adherents into self-chosen isolation at the edge of ancient society.

The author of Revelation might best be regarded as a welleducated Jewish-Christian prophet. There is a deep and general knowledge of the scriptures of Israel. There seems to be a geographic transition from Palestine to Asia Minor, and also a religious transition from Judaism to Christianity. The fact that Revelation's author might have experienced Roman rule in the first Jewish war (Ebner 2011:130-131) is an interesting educated guess that might explain some aspects of the text and its imagery. The person responsible for the book of Revelation, a certain John, was a Christian prophet known to the Christian groups in Asia Minor. His narrative is testimony to an approach that selects insights from different religious streams - from 1st century Judaism and 1st century Christianity - and integrates them into a selective and limited model of Christian attitude towards society and culture. As such, the narrative is not simply conservative, but integrative in so far as it develops a new revelation on old grounds, whose counter-cultural access is based on the transformation of different cultural means. The main, though not exclusive, opposition is the emperor's cult, but its main addressees are Christians who receive both encouragement and criticism.

31.Cf. for example Wengst (1994:198): [ [W] are dealing [...] with the general question of social communication and participation, whether it refers to public festivals connected with the temples and therefore also with the gods, or to private or social festivities in the context of ritual sacrifices in the temples.'
Revelation is an example of productive transformation of religious ideas and backgrounds. This biblical text changes the world outside the narrative by constructing a new textual counter-world. The narrative forms meaning by taking up different streams of concepts and ideas, and thereby builds up an elite group identity that deliberately chooses an outsider position, defined by the narrative formation of meaning, as the insider position with regard to the apocalyptic events that guarantee eternal life and community with God and his Lamb.

\section{Acknowledgements Competing interests}

The author declares that he has no financial or personal relationship(s) that may have inappropriately influenced him in writing this article.

\section{References}

Ameling, W., 2011, 'Der kleinasiatische Kaiserkult und die Öffentlichkeit: Überlegungen zur Umwelt der Apokalypse', in M. Ebner \& E. Esch-Wermeling (eds.), Kaiserkult, Wirtschaft und spectacula: Zum politischen und gesellschaftlichen Umfeld der Offenbarung, pp. 15-54, Vandenhoeck \& Ruprecht, Göttingen. (NTOA 72).

Aune, D.E., 1996-1998, Revelation 1-3, Word/Nelson, Dallas/Nashville. (WBC 52).

Bachmann, M., 2005, 'Apocalypse now, Apocalypse once: Der Film Francis Ford Coppolas auf dem Hintergrund der Johannesoffenbarung,' in F.W. Horn \& M. Wolter (eds.), Studien zur Johannesoffenbarung und ihrer Auslegung: Festschrift für Otto Böcher zum 70. Geburtstag, pp. 381-401, Neukirchener Verlag, Neukirchen-Vluyn.

Bachmann, M., 2012, 'Wo bleibt das Positive? Zu Offb 6,1 f. und 17,5 in Rezeptionsgeschichte und Exegese', in M. Labahn \& M. Karrer (eds.), Die Johannesoffenbarung: Ihr Text und ihre Auslegung, pp. 197-221, Evangelische Verlagsanstalt, Leipzig. (ABG 38).

Balch, D.L., 2006, '“A woman clothed with the sun" and the "Great Red Dragon" seeking to "devour her child" (Rev 12:1, 4) in Roman Domestic Art', in J. Fotopoulos (ed.) The New Testament and early Christian literature in Greco-Roman context: Studies in honor of David E. Aune, pp. 287-314, Brill, Leiden. (NT Sup. 122).

Böcher, O. 1983, 'Israel und die Kirche in der Johannesapokalypse', in O. Böcher (ed.), Kirche in Zeit und Endzeit: Aufsätze zur Offenbarung des Johannes, pp. 28-57, Neukirchener Verlag, Neukirchen-Vluyn.

Boesak, A., 1987, Comfort and protest: Reflections on the Apocalypse of John of Patmos, Eerdmans, Grand Rapids.

Boring, M.E., 1992, 'Narrative Christology in the Apocalypse', CBQ 54, 702-723.

Busse, T., 2000, Weltuntergang als Erlebnis. Apokalyptische Erzählungen in den Massenmedien, DUV, Wiesbaden. http://dx.doi.org/10.1007/978-3-322-83453-9

Collins, A.Y., 1984, Crisis and catharsis. The power of the Apocalypse, The Westminster Press, Philadelphia.

De Villiers, P., 2002, 'Persecution in the book of Revelation', Acta Theologica 2, 47-70.

Dochhorn, J., 2011, Schriftgelehrte Prophetie. Der eschatologische Teufelsfall in Apc Joh 12 und seine Bedeutung für das Verständnis der Johannesoffenbarung, Mohr Siebeck, Tübingen. (WUNT 268).

Duff, P., 2006, "'The Synagogue of Satan": Crisis mongering and the Apocalypse of John', in D.L. Barr (ed.), The reality of Apocalypse: Rhetoric and politics in the book of Revelation, pp. 147-168, Society of Biblical Literature, Atlanta, GA. (SBL SymS 39).

Ebner, M., 2011, 'Spiegelungen: Himmlischer Thronsaal und himmlische Stadt. Theologie und Politik in Offb 4f. und 21f.', in B. Heininger (ed.), Mächtige Bilder: Zeit- und Wirkungsgeschichte der Johannesoffenbarung, pp. 100-131, Katholisches Bibelwerk, Stuttgart. (SBS 225).

Ego, B., 2006, 'Reduktion, Amplifikation, Interpretation, Neukontextualisierung. Intertextuelle Aspekte der Rezeption der Ezechielschen Thronwagenvision im antiken Judentum', in D. Sänger (ed.), Das Ezechielbuch in der Johannesoffenbarung, pp. 31-60, Neukirchener Verlag, Neukirchen-Vluyn. (Biblisch-theologische Studien 76)

Esch-Wermeling, E., 2011, 'Brückenschläge: Die alttestamentlichen Traditionen der Offenbarung und Anspielungen auf die Zeitgeschichte. Methodische Überlegungen und Fallbeispiele', in M. Ebner \& E. Esch-Wermeling (eds.), Kaiserkult, Wirtschaft und spectacula: Zum politischen und gesellschaftlichen Umfeld der Offenbarung, pp. 139-163, Vandenhoeck \& Ruprecht, Göttingen. (NTOA 72).

Frankfurter, D., 2001, 'Jews or not? Reconstructing the "Other" in Rev. 2:9 and 3:9', HTR 94, 403-425.

Frenschkowski, M., 2005, 'Die Johannesoffenbarung zwischen Vision, astralmythologischer Imagination und Literatur. Perspektiven und Desiderate der Apokalypse-Forschung', in F.W. Horn \& M. Wolter (eds.), Studien zur Johannesoffenbarung und ihrer Auslegung: Festschrift für Otto Böcher zum 70. Geburtstag, pp. 20-45, Neukirchener Verlag, Neukirchen-Vluyn. 
Friesen, S. J., 2006, 'Sarcasm in Revelation 2-3: Churches, Christians, true Jews, and Satanic Synagogues', in D.L. Barr (ed.), The reality of Apocalypse: Rhetoric and politics in the book of Revelation, 127 . 127-144, Society of Biblical Literature, politics in the book of Reveld
Atlanta, GA. (SBL SymS 39).

Giesen, H., 2012, 'Der Christustitel "Lamm" in der Offenbarung des Johannes und sein religionsgeschichtlicher Hintergrund', in M. Labahn \& M. Karrer (eds.), Die Johannesoffenbarung: Ihr Text und ihre Auslegung, pp. 173-196, Evangelische Verlagsanstalt, Leipzig. (ABG 38)

Hieke, T. \& Nicklas, T., 2003, 'Die Worte der Prophetie diese Buches': Offenbarung 22, 6-21 als Schlussstein der christlichen Bibel Alten und Neuen Testaments gelesen, Neukirchener Verlag, Neukirchen-Vluyn. (BThSt 62).

Hirschberg, P., 1999, Das eschatologische Israel: Untersuchungen zum Gottesvolkverständnis der Johannesoffenbarung, Neukirchener Verlag, Neukirchen-Vluyn. (WMANT 84).

Kalms, J.U., 2001, Der Sturz des Gottesfeindes: Traditionsgeschichtliche Studien zu Apokalypse 12, Neukirchener Verlag, Neukirchen-Vluyn. (WMANT 93)

Karrer, M., 2005, 'Ein optisches Instrument in der Hand der Leser: Wirkungsgeschichte und Auslegung der Johannesoffenbarung', in F.W. Horn \& M. Wolter (eds.), Studien zur Johannesoffenbarung und ihrer Auslegung Festschrift für Otto Böcher zum 70. Geburtstag, pp. 402-432, Neukirchene Verlag, Neukirchen-Vluyn.

Karrer, M., 2012, 'Apoll und die apokalyptischen Reiter', in M. Labahn \& M. Karre (eds.), Die Johannesoffenbarung: Ihr Text und ihre Auslegung, pp. 223-251, Evangelische Verlagsanstalt, Leipzig. (ABG 38).

Karrer, M., 2013, 'Hellenistische und frühkaiserzeitliche Motive in de Johannesapokalypse', in T. Schmeller \& M. Ebner (eds.), Die Offenbarung des Johannes. Kommunikation im Konflikt, pp. 32-73, Herder, Freiburg. (Quaestiones Johannes. Komm).
Disputatae 253)

Krah, H., 2004, Weltuntergangsszenarien und Zukunftsentwürfe: Narrationen vom 'Ende' in Literatur und Film 1945-1990, Verlag Ludwig, Kiel. (LIMES 4).

Labahn, M., 2002, 'Heiland der Welt: Der gesandte Gottessohn und der römische Kaiser - ein Thema johanneischer Christologie?', in M. Labahn \& J. Zangenber (eds.), Zwischen den Reichen: Neues Testament und Römische Herrschaft, pp. 147-173, Francke, Tübingen. (TANZ 36).

Labahn, M., 2010, 'Die Macht des Gedächtnisses: Überlegungen zu Möglichkeit und Grenzen des Einflusses hebräischer Texttradition auf die Johannesapokalypse', in M. Karrer, S. Kreuzer \& M. Sigismund (eds.), Von der Septuaginta zum Neuen Testament: Textgeschichtliche Erörterungen, pp. 385-416, De Gruyter, Berlin. (ANTT 43).

Labahn, M., 2011a, 'Teufelsgeschichten: Satan und seine Helfer in de Johannesapokalypse', Zeitschrift für Neues Testament 14(28), 33-42.

Labahn, M., 2011b, “'Apokalyptische Geographie”. Einführende Überlegungen zu einer Toponomie der Johannesoffenbarung', in M. Labahn \& O. Lehtipuu (eds.) Imagery in the book of Revelation, pp. 107-143, Peeters, Leuven. (CBET 60).

Labahn, M., 2012, 'The resurrection of the followers of the Lamb: Between heavenly "reality" and hope for the future. The concept of resurrection within the imagery of death and life in the book of Revelation', in G. van Oyen \& T. Shepherd (eds.) Resurrection of the dead: Bible traditions in dialogue, pp. 319-342, Peeters, Leuven. (BETL 249).

Labahn, M., 2013a, “"Das Buch dieser Prophetie” - die Schriften Israels und die Schrift des Sehers. Überlegungen zur Schrifthermeneutik der Johannesoffenbarung', in
B.J. Koet, S. Moyise \& J. Verheyden (eds.), The Scriptures of Israel in Jewish and B.J. Koet, S. Moyise \& J. Verheyden (eds.), The Scriptures of Israel in Jewish and
Christian tradition. Essays in honour of Maarten J.J. Menken, pp. 265-283, Brill, Christian tradition. Essays
Leiden. (NT Sup. 148).

Labahn, M., 2013b, 'The dangerous loser: The narrative and rhetorical function of the devil as character in the book of Revelation', in I. Fröhlich \& E. Koskenniemi (eds.), Evil and the devil, pp. 156-179, Bloomsbury, London. (LNTS $481=$ ESCO).

Labahn, M., 2014, '“Gefallen, gefallen ist Babylon die Große”. Die Johannesoffenbarung als subversive Erzählung', in J. Elschenbroich \& J. de Vries (eds.), Worte der Weissagung. Studien zu Septuaginta und Johannesoffenbarung, pp. 319-341, Weissagung. Studien zu Septuaginta und Johan
Evangelische Verlagsanstalt, Leipzig. (ABG 47).

Lambrecht, J., 2001, "'Synagogues of Satan" (Rev. 2:9 and 3:9): Anti-Judaism in the book of Revelation', in R. Bieringer \& D. Pollefeyt (eds.), Anti-Judaism and the Fourth Gospel: Papers of the Leuven Colloquium - 2000, pp. 514-530, Van Gorcum, Assen. (Jewish and Christian Heritage Series 1).

Maier, H.O., 2005, 'The President's Revelation: The Apocalypse, American providence, and the war on terror,' Word and World 25, 294-307.

Mazenik, C., 2011, 'Bildhafte Theologie ins Bild gesetzt: Die Offenbarung des Johannes in ihrem Verhältnis zur Kunst als tröstende (Heraus-)Forderung für ein Christ-Sein heute', in G. Riedl, M. Negele \& C. Mazenik (eds.), Apokalyptik; Zeitgefühl mit Perspektive, pp. 189-225, Schöningh, Paderborn.

Mucha, R., 2014, 'Ein flavischer Nero: Zur Domitian-Darstellung und Datierung der Johannesoffenbarung', NTS 60, 83-105. http://dx.doi.org/10.1017/ S0028688513000295

Müller, K., 2011, 'Noch einmal die Einhundertvierundvierzigtausend. Anmerkungen zur judenchristlichen Kompetenz des Verfassers der Johannesapokalypse', in B. Heininger (ed.), Mächtige Bilder. Zeit- und Wirkungsgeschichte de Johannesoffenbarung, pp. 132-166, Katholisches Bibelwerk, Stuttgart. (SBS 225).

Nicklas, T., 2009, " 'Die Seelen der Geschlachteten" (Offb 6,9)? Zum Problem leiblicher Auferstehung in der Offenbarung des Johannes', in T. Nicklas \& F.V. Reiterer (eds.) The human body in death and resurrection, pp. 329-349, De Gruyter, Berlin (Deuterocanonical and Cognate Literature Yearbook 2009).

Omerzu, H., 2006, 'Die Himmelsfrau in Apk 12. Ein polemischer Reflex des römischen Kaiserkults', in M. Becker \& M. Öhler (eds.), Apokalyptik als Herausforderung neutestamentlicher Theologie, pp. 167-194, Mohr Siebeck, Tübingen. (WUNT II/214)
Pezzoli-Olgiati, D., 2002, 'Between fascination and destruction. Considerations on the power of the Beast in Rev 13:1-10', in M. Labahn \& J. Zangenberg (eds.), Zwischen den Reichen: Neues Testament und Römische Herrschaft, pp. 229-237, Francke, den Reichen: Neues
Tübingen. (TANZ 36).

Porsch, F., 2000, 'Die Johannesoffenbarung als "subversive Literatur"', Bulletin Dei Verbum 54, 13-15.

Räisänen, H., 2009, 'Revelation, violence, and war: Glimpses of a dark side,' in W.J. Lyons \& J. Økland (eds), The way the world ends? The Apocalypse of John in culture and ideology, pp. 151-165, Sheffield Phoenix Press, Sheffield. (The Bible in the Modern World 19).

Resseguie, J.L., 1998, Revelation unsealed. A narrative critical approach to John's Apocalypse, Brill, Leiden. (BIS 32).

Resseguie, J.L., 2009, The Revelation of John. A narrative commentary, Baker Academic, Grand Rapids.

Rüsen, J., 2006, Kultur macht Sinn. Orientierung zwischen Gestern und Morgen, Böhlau, Köln.

Rustemeyer, D., 2000, 'Welt im Text? Kurt Röttgers Theorie kommunikativer Texte und die Lineatur der Geschichte', Journal für Phänomenologie 14, 52-58.

Schnelle, U., 2008, Theologie des Neuen Testaments, Vandenhoeck \& Ruprecht, Göttingen. (UTB 2917).

Schreiber, S., 2008, 'Die Lamm-Perspektive. Bemerkungen zu Offb 5', in F.R. Prostmeier L. Hauser \& C. Georg-Zöller (eds.), Jesus als Bote des Heils. Heilsverkündigung und Heilserfahrung in frühchristlicher Zeit. FS D. Dormeyer, pp. 294-307, Katholisches Bibelwerk, Stuttgart. (SBB 60).

Schreiber, S., 2013, 'Attraktivität und Widerspruch. Die Dämonisierung der römischen Kultur als narrative Strategie in der Offenbarung des Johannes', in T. Schmeller \& M. Ebner (eds)., Die Offenbarung des Johannes. Kommunikation im Konflikt, pp. 74-106, Herder, Freiburg. (Quaestiones disputatae 253)

Siitonen, K., 2011, 'Merchants and commerce in the book of Revelation', in M. Labahn \& O. Lehtipuu (eds.), Imagery in the book of Revelation, pp. 145-160, Peeters, Leuven. (CBET 60)

Söding, T., 2001, 'Gott und das Lamm. Theozentrik und Christologie in der Johannesapokalypse', in K. Backhaus (ed.), Theologie als Vision. Studien zur Johannes-Offenbarung, pp. 77-120, Katholisches Bibelwerk, Stuttgart. (SBS 191).

Stowasser, M., 2013, 'Synagoge des Satans. Innerjüdische Bruchlinien in der Offenbarung des Johannes', in T. Schmeller \& M. Ebner (eds)., Die Offenbarung des Johannes. Kommunikation im Konflikt, pp. 137-164, Herder, Freiburg. (Quaestiones disputatae 253).

Theissen, G., 2003, 'Jünger als Gewalttäter (Mt 11,12f; Lk 16,16). Der Stürmerspruch als Selbststigmatisierung einer Minorität', in idem, Jesus als historische Gestalt. Beiträge zur Jesusforschung. Zum 60. Geburtstag, ed. by Annette Merz, pp. 153168, Vandenhoeck \& Ruprecht, Göttingen. (FRLANT 202).

Tilly, M., 2005, ,Textsicherung und Prophetie. Beobachtungen zur SeptuagintaRezeption in Apk 22,18f', in F.W. Horn \& M. Wolter (eds.), Studien zur
Johannesoffenbarung und ihrer Auslegung; Festschrift für Otto Böcher zum 70. Geburtstag, pp. 232-247, Neukirchener Verlag, Neukirchen-Vluyn.

Timpe, D., 2009, 'Domitian als Christenfeind und die Tradition der Verfolgerkaiser,' in J. Frey \& S. Krauter (eds.), Heil und Geschichte. Die Geschichtsbezogenheit des Heils und das Problem der Heilsgeschichte in der biblischen Tradition und in der theologischen Deutung, pp. 213-242, Mohr Siebeck, Tübingen. (WUNT 248).

Ulland, H., 1997, Die Vision als Radikalisierung der Wirklichkeit in der Apokalypse des Johannes, Francke, Tübingen. (TANZ 21).

Van Henten, J.W., 2006, 'Dragon myth and imperial ideology in Revelation 1213 ', in D.L. Barr (ed.), The reality of Apocalypse; Rhetoric and politics in the book of Revelation, pp. 181-203, Society of Biblical Literature, Atlanta, G.A. (SBL SymS 39).

Venetz, H-J., 1999, Das Buch der subversiven Hoffnung; Zugänge zur Johannesoffenbarung, Kanisius, Freiburg.

Vischer, E., 1886, Die Offenbarung Johannis; Eine jüdische Apokalypse in christlicher Bearbeitung, Hinrichs, Leipzig. (TU 2/3).

Wengst, K., 1994, 'Babylon the Great and the New Jerusalem: The visionary view of political reality in the Revelation of John', in H. Graf Reventlow, Y. Hoffmann \& B. Uffenheimer (eds.), Politics and theopolitics in the Bible and postbiblical literature, pp. 189-202, JSOT Press, Sheffield. (JSOTS 171).

Wengst, K. 2010, 'Wie lange noch?' Schreien nach Recht und Gerechtigkeit - eine Deutung der Apokalypse des Johannes, Kohlhammer, Stuttgart.

Wikipedia, n.d.a, Axis of evil, viewed 14 April 2012, from http://en.wikipedia.org/wiki/ Axis_of_evil

Wikipedia, n.d.b, Reich des Bösen, viewed 10 April 2012, from http://de.wikipedia. org/wiki/Reich_des_B\%C3\%B6sen

Witetschek, S., 2008, Ephesische Enthüllungen 1: Frühe Christen in einer antiken Großstadt: Zugleich ein Beitrag zur Frage nach den Kontexten der Johannesapokalypse, Peeters, Leuven. (Biblical Tools and Studies 6).

Witetschek, S., 2012, 'Ein weit geöffnetes Zeitfenster? Überlegungen zur Datierung der Johannesapokalypse', in J. Frey \& J.A. Kelhoffer (eds.), Die Johannesapokalypse. Kontexte - Konzepte - Rezeption, pp. 117-148, Mohr Siebeck, Tübingen (WUNT 287).

Witulski, T., 2007, Die Johannesoffenbarung und Kaiser Hadrian: Studien zur Datierung der neutestamentlichen Apokalypse, Vandenhoeck \& Ruprecht, Göttingen. (FRLANT 221)

Witulski, T., 2012, 'Der römische Kaiser Hadrian und die neutestamentliche Johannesapokalypse', in J. Frey \& J.A. Kelhoffer (eds.), Die Johannesapokalypse. Kontexte - Konzepte - Rezeption, pp. 79-115, Mohr Siebeck, Tübingen. (WUNT 287). 